\title{
Baseline evaluation of Project Mesha in Bihar: Factsheet results 2017-2018
}

Population Council

Follow this and additional works at: https://knowledgecommons.popcouncil.org/departments_sbsr-rh

Part of the Civic and Community Engagement Commons, Demography, Population, and Ecology Commons, Family, Life Course, and Society Commons, and the International Public Health Commons How does access to this work benefit you? Let us know!

\section{Recommended Citation}

Population Council. 2018. "Baseline evaluation of Project Mesha in Bihar: Factsheet results 2017-2018." New Delhi: Population Council. 


\section{Fact Sheet Results: 2017-2018}

Aga Khan Foundation is implementing 'Project Mesha', a community-based program to develop the potential of goat farming among women goat rearers in four blocks of Muzaffarpur district of Bihar. The aim of the project is to increase the income and empowerment of women goat rearers through the implementation of Project Mesha in JEEViKA-run self-help groups (SHGs).

The Population Council conducted the baseline evaluation survey at the end of 2017 among women who were the primary decision makers in the rearing of goats. Women were interviewed across two study geographies - blocks where Mesha project will be implemented and blocks where Mesha project will not be implemented. From each area, women who were SHG members and non-members were interviewed. The findings are based on responses from two groups of women (a) women who are primary goat rearers henceforth referred to as regular women (RW), and (b) women who've given birth in the last two years and are also the primary goat rearers, henceforth referred to as eligible women (EW). The indicators ${ }^{1}$ below include basic socio-demographic characteristics and profile of the households. Indicators around ownership of goats, along with goat morbidity and mortality have been captured from household interviews. Women's own income, their contribution to household income as well as income from the sale of goats is recorded. Empowerment of women is measured through their role and decision-making around goat rearing, income and productive resources, access to resources, decision-making around production and income generation, access to productive capital, access to credit, freedom in mobility, self-confidence, financial empowerment and inclusion, and group membership.
Goat morbidity and mortality rates are high: In the Mesha and non-Mesha areas, goat morbidity and mortality are high. This can be explained by lower vaccination and deworming rates. Hence, the role of pashu sakhis is vital.

Loan taking for goat or cattle rearing is low: Around $60 \%$ of women have taken a loan. However, loan taken for goat or cattle rearing is substantially low. Women in the intervention area can be encouraged to utilize loans for initiating enterprises on rearing of small ruminants.

Goat rearing supports income generation: Yearly income generated from small ruminants is significantly higher when households have higher number of goats and when women negotiate the sale of goats. Currently, about $40 \%$ of women negotiate the sale of goats, and the intervention can improve women's negotiation skills.

Individual empowerment is low across all women: Women have limited autonomy within their families, be it decision making, freedom in mobility or access to productive capital. However, self-confidence, especially among SHG members was higher and can be capitalized on.
- Average age of women goat rearers is 38 years, more than two-thirds have no schooling and one in every four women are currently working.

- The reported monthly income of working women is about Rs.1000.

- Majority of respondents are Hindu, and from other backward class.

-About half of the goat rearer households in the Mesha area are in the lowest/lower socio-economic strata.

- More than $50 \%$ of families are nuclear, and about 1 in every 5 women's husband is a migrant.

\section{Socio-demographics}

\section{Women in age group 15 - 24 yrs (\%)}

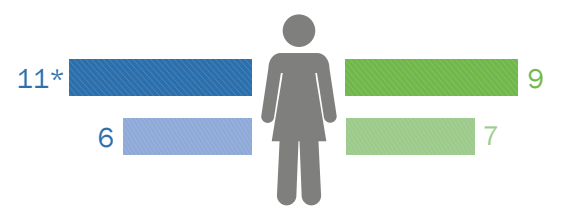

\section{Average age of women, in yrs}

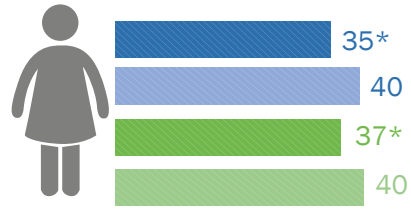

Currently working (\%)

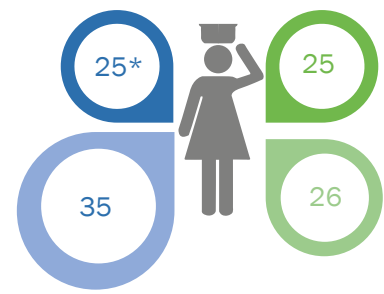

Husband is a migrant (\%)

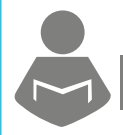

Average monthly income (₹)

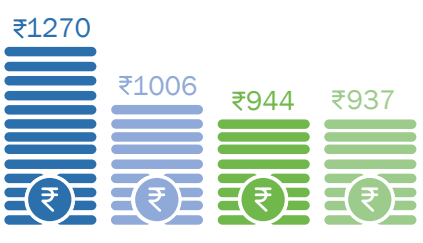

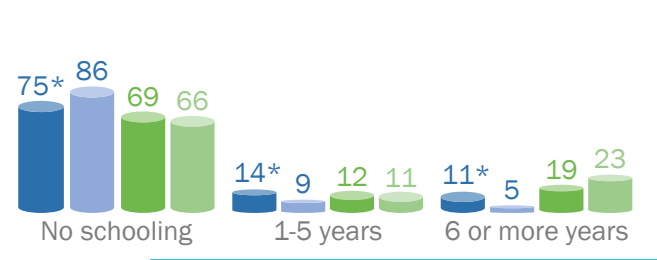
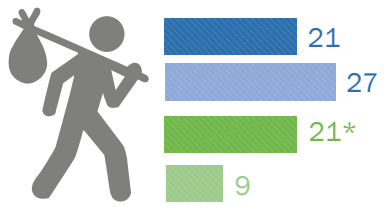

\section{Household profile}

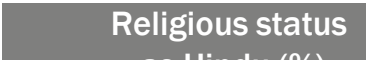
as Hindu (\%)

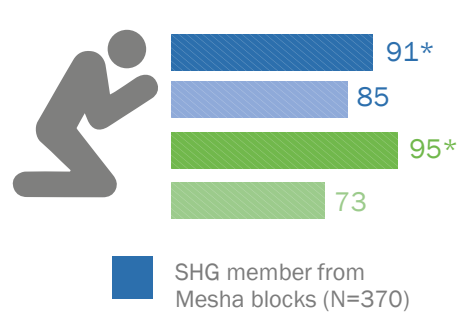

Mesha blocks $(\mathrm{N}=370)$
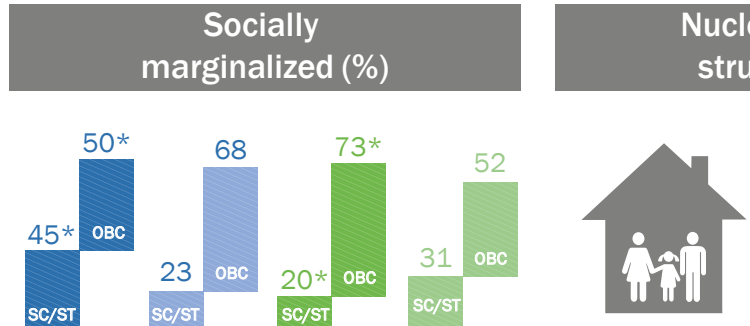

Nuclear family structure (\%)

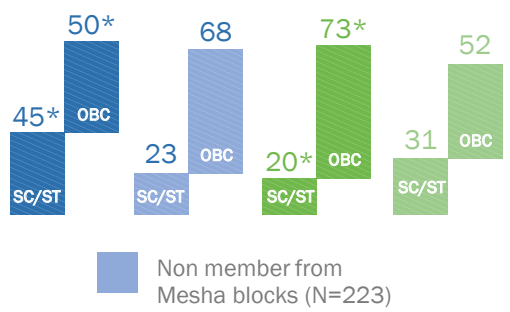

Mesha blocks $(\mathrm{N}=223$

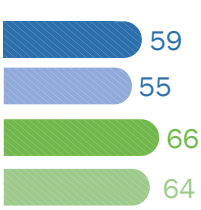

SHG member from non - Mesha blocks ( $N=294)$
Lowest / lower wealth quintile (\%) 
- Less than $25 \%$ of households in the Mesha area and about $50 \%$ in the non-Mesha area have improved sanitation. Use of clean fuel for cooking is remarkably low.

- Goat mortality is high. Herd size as well as goat morbidity are significantly higher in Mesha areas than non-Mesha areas.

-Very few women received training on goat rearing. A very small proportion of women can recognize signs of goat morbidity. The intervention could focus on recognizing early signs of morbidity.

\section{Household profile}

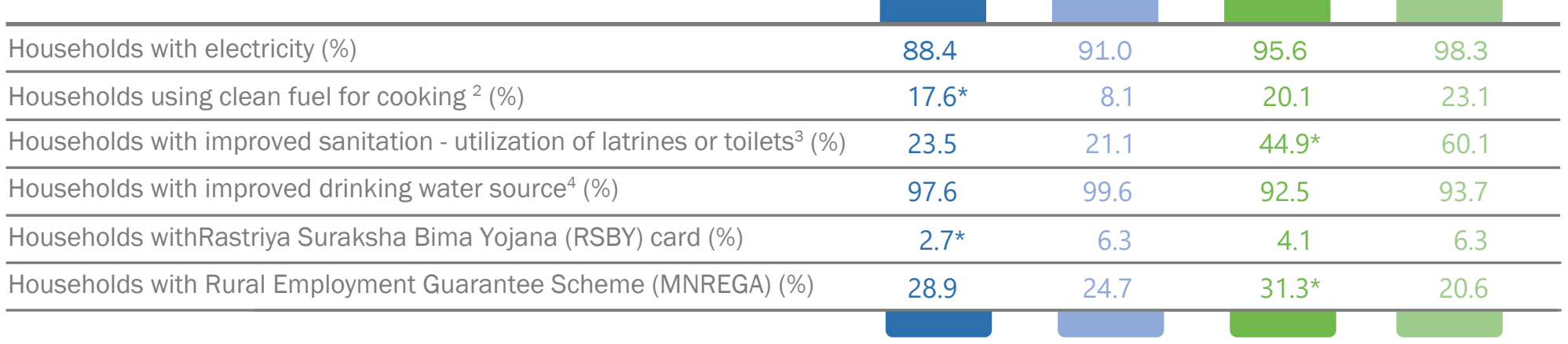

\section{Goat ownership, mortality and morbidity}

Goats in SHG households from
Mesha blocks $(\mathrm{N}=9,157)$
Goats in non-SHG households from
Mesha blocks $(\mathrm{N}=1,003)$
Goats in SHG households from
non-Mesha blocks $(\mathrm{N}=4,528)$
Goats in non-SHG households from
non-Mesha blocks $(\mathrm{N}=1,299)$

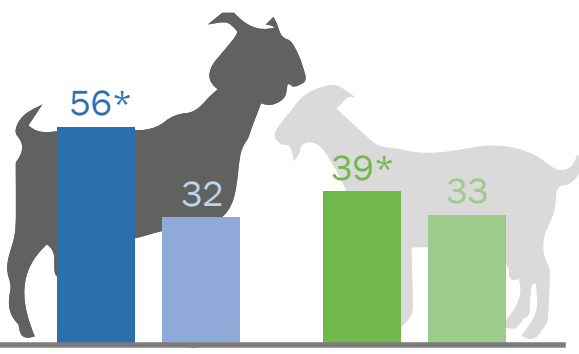

Households have been involved in goat rearing at any time in the past one year (\%)
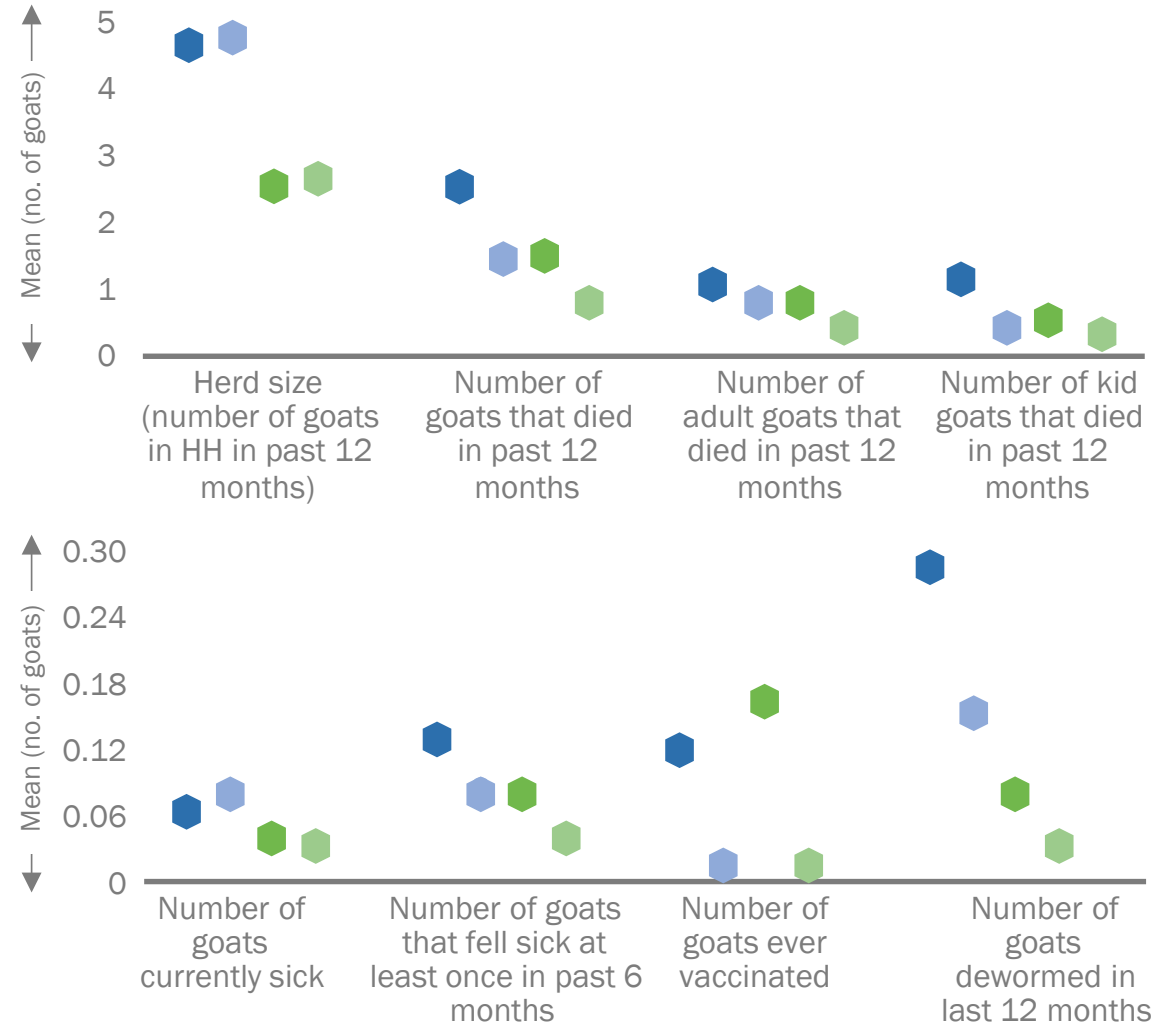

\section{Goat rearing, income and productive resources}

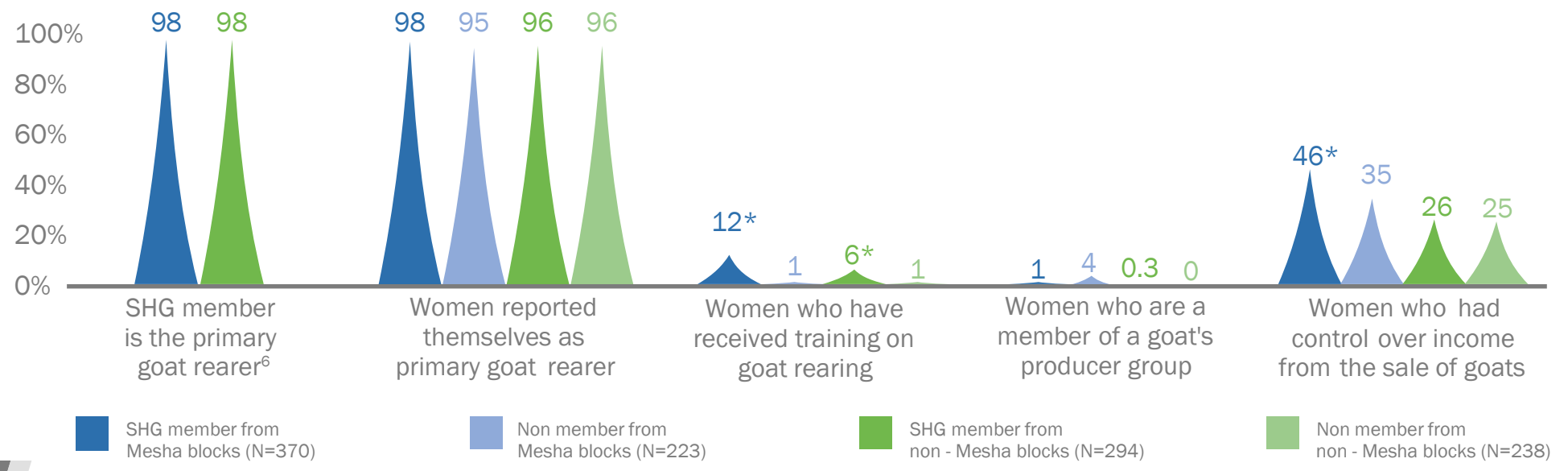


- Yearly income from goat rearing is higher in the Mesha area ( Rs.1170) than non-Mesha area ( Rs.840).

- Access to schemes such as take home ration and use of Antyodaya Yojna are low, while 50-80\% women access Integrated Child Development Services (ICDS) and Public Distribution System (PDS)

- Overall, a low proportion of women have decision making power on purchasing livestock/livelihood activities, selling of products from livelihood activities, taking loan, expenditure on own/child's health and major household expenditures.

\section{Goat rearing, income and productive resources}

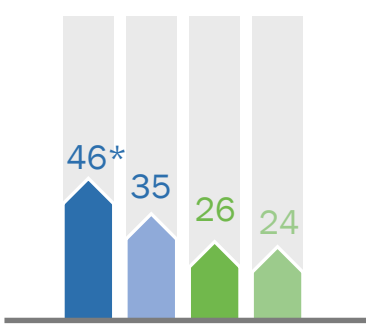

Women who used income generated by small ruminants by herself (\%)

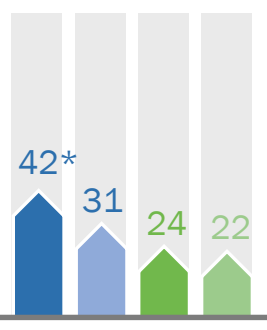

Women who negotiate the sale of goats (\%)

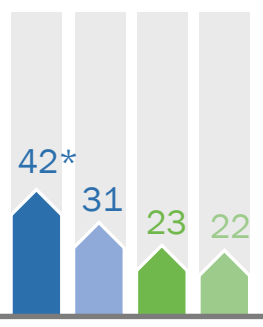

Women who are the primary caregiver and negotiate the sale of goats (\%)

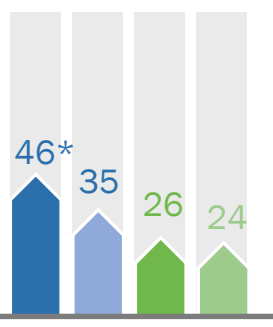

Women who are primary caregiver and keep income from sale of goats (\%)

\section{Access to schemes}

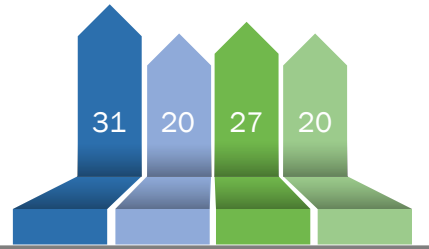

Received take home ration from AWC during the last pregnancy (\%)
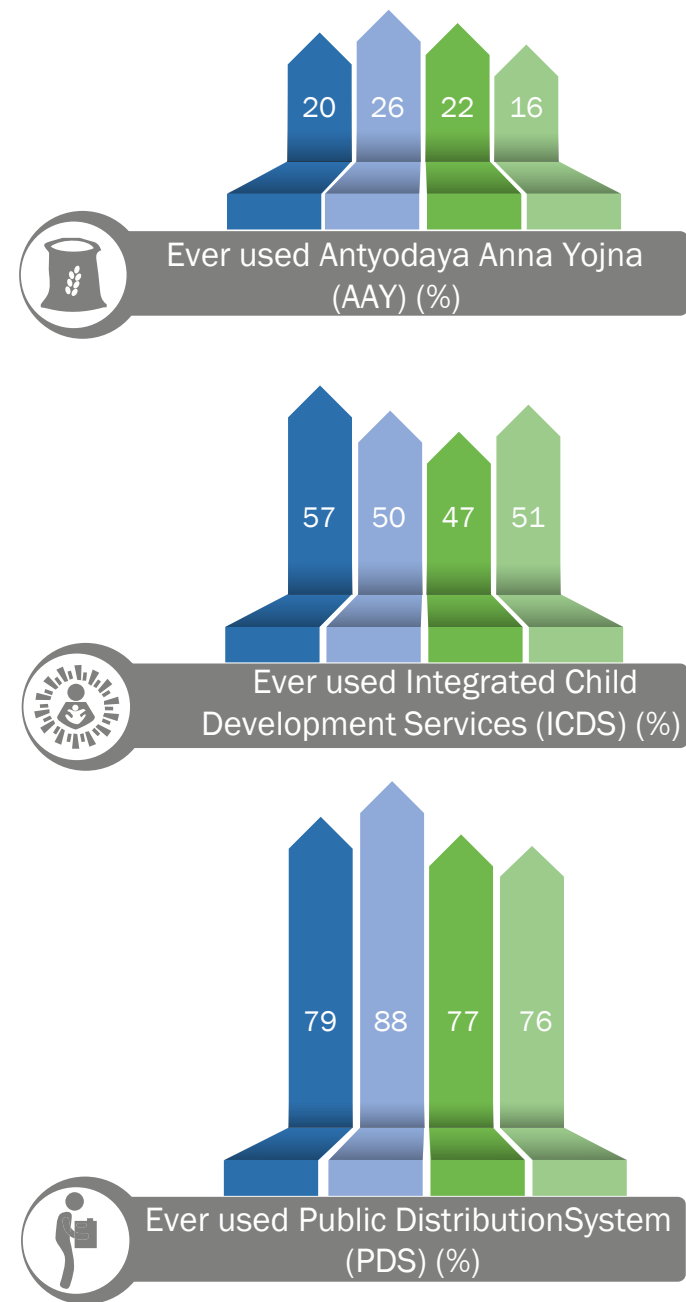

Decision making

\begin{tabular}{|c|c|c|c|c|}
\hline $\begin{array}{l}\text { Women who } \\
\text { self decide on }\end{array}$ & $\begin{array}{l}\text { SHG } \\
\text { member } \\
\text { from } \\
\text { Mesha } \\
\text { blocks }\end{array}$ & $\begin{array}{l}\text { Non } \\
\text { member } \\
\text { from } \\
\text { Mesha } \\
\text { blocks }\end{array}$ & $\begin{array}{c}\text { SHG } \\
\text { member } \\
\text { from } \\
\text { non- } \\
\text { Mesha } \\
\text { blocks }\end{array}$ & $\begin{array}{l}\text { Non- } \\
\text { member } \\
\text { from } \\
\text { non- } \\
\text { Mesha } \\
\text { blocks }\end{array}$ \\
\hline Use of contraception (\%) & 21.0 & 22.1 & $24.5 *$ & 16.8 \\
\hline $\begin{array}{l}\text { Purchase livestock or other } \\
\text { livelihood activities (\%) }\end{array}$ & 30.5 & 33.9 & 29.9 & 26.1 \\
\hline $\begin{array}{l}\text { Selling of products } \\
\text { resulting from livelihood } \\
\text { activities (\%) }\end{array}$ & 17.0 & 16.7 & 17.3 & 11.1 \\
\hline $\begin{array}{l}\text { Expenditure on own } \\
\text { health (\%) }\end{array}$ & 26.6 & 26.7 & 30.3 & 23.1 \\
\hline $\begin{array}{l}\text { Expenditure on } \\
\text { children's health (\%) }\end{array}$ & 30.1 & 29.0 & $33.4 *$ & 23.3 \\
\hline $\begin{array}{l}\text { Taking loan from any } \\
\text { source (\%) }\end{array}$ & 18.6 & 13.4 & 20.1 & 14.1 \\
\hline Food crop farming (\%) & 16.6 & 20.6 & 15.7 & 7.7 \\
\hline Cash crop farming (\%) & 13.0 & 16.6 & 14.0 & 15.0 \\
\hline Livestock raising (\%) & 50.5 & 59.7 & 53.4 & 55.8 \\
\hline $\begin{array}{l}\text { Non- farming economic } \\
\text { activity }(\%)\end{array}$ & 17.0 & 16.7 & 17.3 & 11.1 \\
\hline $\begin{array}{l}\text { Major household } \\
\text { expenditures (\%) }\end{array}$ & 13.7 & 13.1 & 13.4 & 12.0 \\
\hline $\begin{array}{l}\text { Minor household } \\
\text { expenditures (\%) }\end{array}$ & 50.8 & 52.2 & $56.2 *$ & 45.9 \\
\hline $\begin{array}{l}\text { SHG member from } \\
\text { non - Mesha blocks ( } N\end{array}$ & $N=294)$ & & \multicolumn{2}{|c|}{$\begin{array}{l}\text { Non member from } \\
\text { non } \text { - Mesha blocks }(\mathrm{N}=238)\end{array}$} \\
\hline
\end{tabular}


- Less than $20 \%$ of women make their own decisions to use money from formal/informal lenders or friends/relatives or informal savings group.

- Women's mobility is also restricted; about $60-80 \%$ women require permission to step out of their homes. Mobility is a critical requirement for women rearing goats to access producer groups and markets.

\begin{tabular}{lllll}
$\begin{array}{l}\text { Inputs provided in most } \\
\text { or all decisions for/ on }\end{array}$ & & & & \\
\cline { 2 - 5 } & & & & \\
\hline Food crop farming (\%) & 34.5 & 38.4 & 32.7 & 23.4 \\
\hline Cash crop farming (\%) & 25.7 & 30.1 & 23.9 & 27.3 \\
\hline Livestock raising (\%) & 53.9 & 63.4 & 59.7 & 61.2 \\
\hline $\begin{array}{l}\text { Non - farm economic } \\
\text { activity (\%) }\end{array}$ & 24.1 & 25.6 & 25.1 & 20.8 \\
\hline $\begin{array}{l}\text { Major household } \\
\text { expenditures (\%) }\end{array}$ & 20.9 & 27.6 & 24.4 & 25.6 \\
\hline $\begin{array}{l}\text { Minor household } \\
\text { expenditures (\%) }\end{array}$ & 52.6 & 58.7 & 56.2 & 52.4 \\
\hline $\begin{array}{l}\text { Use of income from food } \\
\text { crop farming (\%) }\end{array}$ & 32.0 & 37.0 & 31.9 & 22.4 \\
\hline $\begin{array}{l}\text { Use of income from cash } \\
\text { crop farming (\%) }\end{array}$ & 21.2 & 25.4 & 21.0 & 24.6 \\
\hline $\begin{array}{l}\text { Use of income from } \\
\text { livestock raising (\%) }\end{array}$ & 47.5 & 51.9 & 48.8 & 48.4 \\
\hline $\begin{array}{l}\text { Use of income from non- } \\
\text { farm economic activities (\%) }\end{array}$ & 20.3 & 28.4 & 24.6 & 20.3 \\
\hline & & & & \\
\hline
\end{tabular}

\section{Decision making}

On use of money from formal lenders (\%)

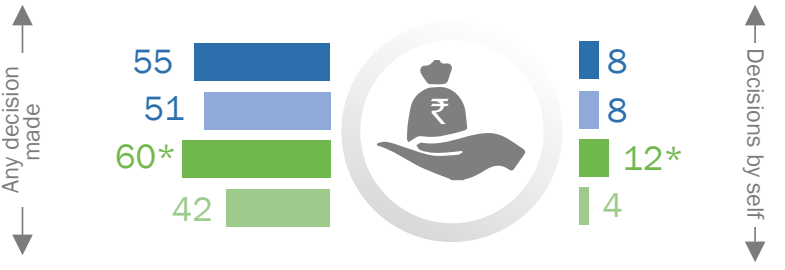

\section{On use of money from informal lenders (\%)}

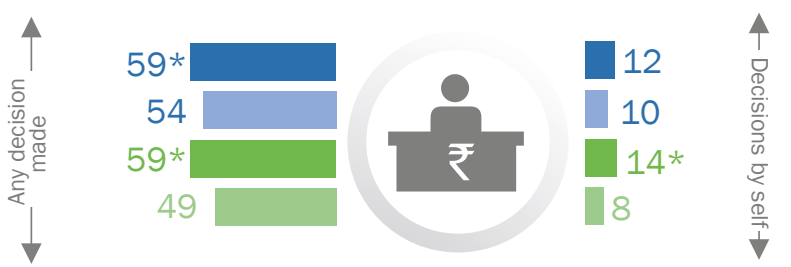

On use of money from friends and relatives (\%)

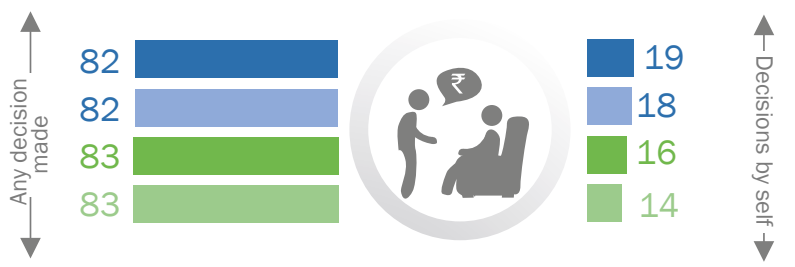

On use of money from informal savings group (\%)

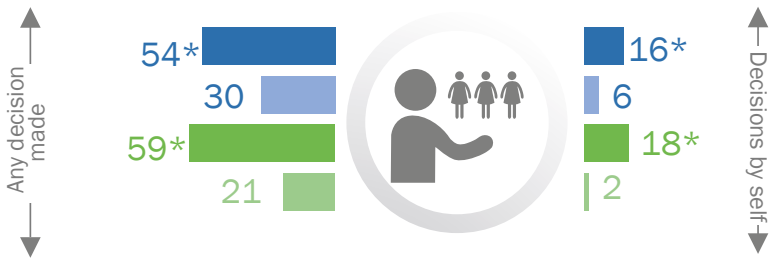

\section{Mobility}

Women who do not need permission for

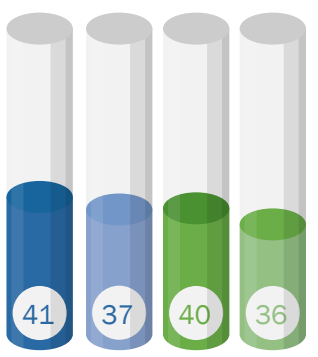

Attending recreational activities (\%)

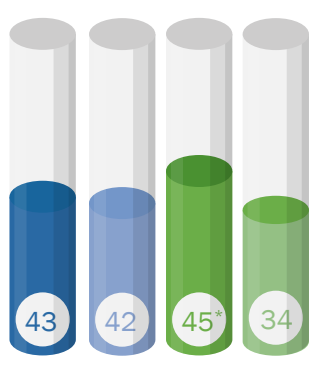

Going to the temple / church/mosque (\%)

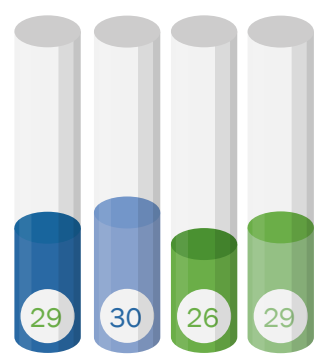

Buying new clothes for herself $(\%)$

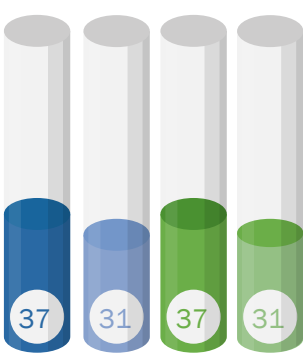

Taking child to health care center (\%)

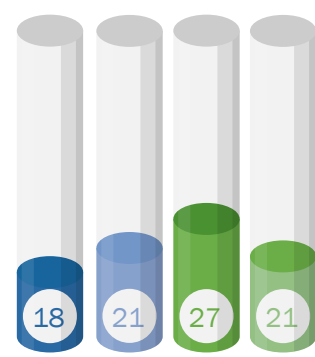

Going to a movie (\%)

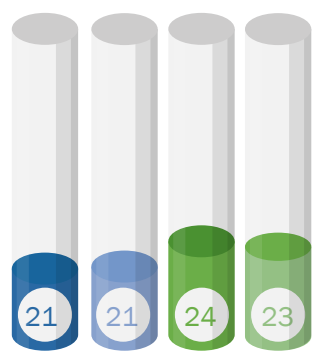

Using family planning methods (\%)

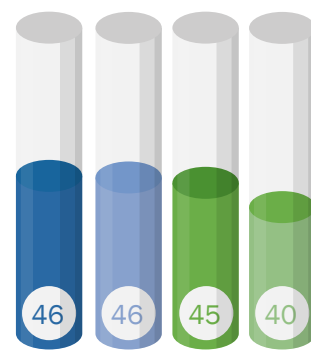

Going to a shop (\%)

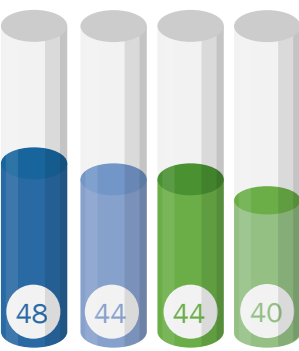

Attending $\mathrm{VHSND}^{7}$ immunization camp (\%)

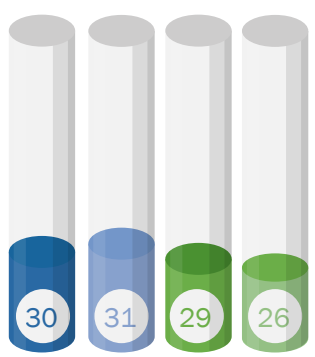

Going to a doctor for own treatment (\%)

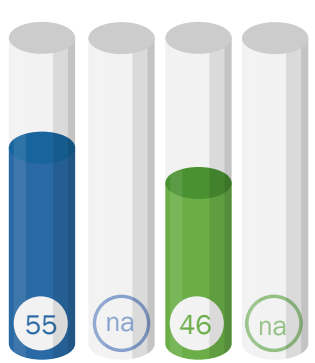

Participating in group meetings (\%) 


\section{Self confidence}

\section{Giving advice on safe maternal health practices (\%)}
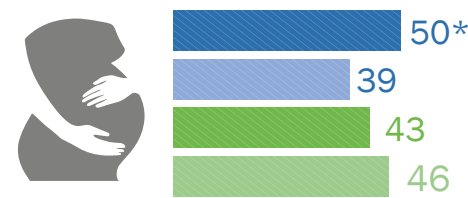

Recognizing child health danger signs (\%)

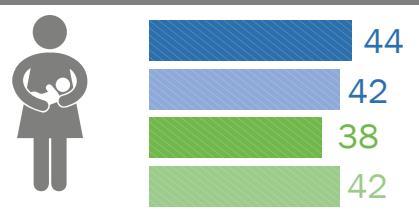

Recognizing maternal danger signs (\%)

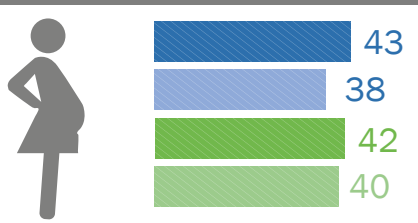

Talking to ASHA/ANM/AWW (\%)

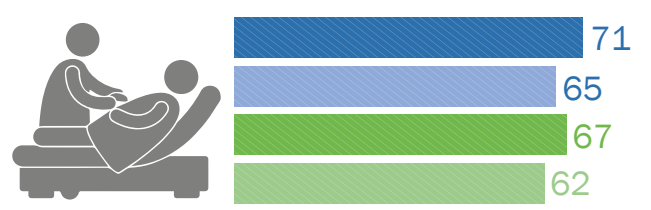

Going to government health facilities (\%)

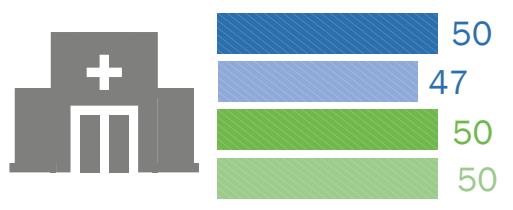

Going to Anganwadi Center for services (\%)

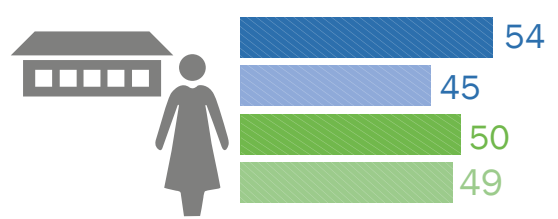

Speaking their opinion (\%)

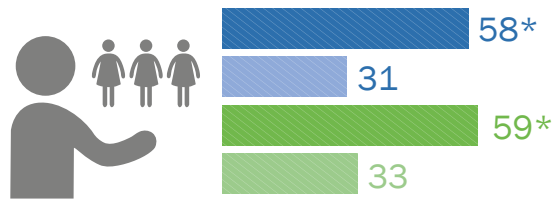

Talking to a bank manager (\%)

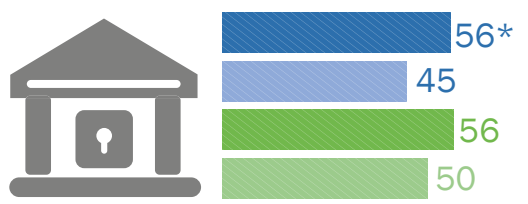

Talking to Sarpanch / Pradhan (\%)

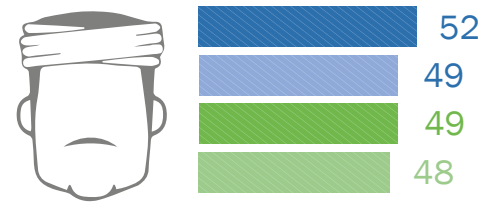

\section{Financial empowerment and inclusion}

\begin{tabular}{|c|c|c|c|c|}
\hline $\begin{array}{l}\text { Women are involved in } \\
\text { major household } \\
\text { economic decisions (\%) }\end{array}$ & 25.9 & 33.1 & 27.4 & 25.8 \\
\hline $\begin{array}{l}\text { Women contribute in } \\
\text { household income (\%) }\end{array}$ & 21.8 & 27.4 & 19.2 & 19.2 \\
\hline $\begin{array}{l}\text { Women have control } \\
\text { over how to spend self- } \\
\text { earned money (\%) }\end{array}$ & 48.6 & 45.0 & 50.5 & 45.2 \\
\hline $\begin{array}{l}\text { Women have their own } \\
\text { source of income (cash } \\
\text { or kind) }(\%)\end{array}$ & 25.7 * & 33.5 & 26.2 & 24.3 \\
\hline $\begin{array}{l}\text { Women save weekly in } \\
\text { the group (\%) }\end{array}$ & 97.8 & - & 99.3 & - \\
\hline $\begin{array}{l}\text { Women own and operate } \\
\text { bank account } \quad(\%)\end{array}$ & 78.5 & 79.2 & $86.6 *$ & 65.6 \\
\hline $\begin{array}{l}\text { Women have taken loan } \\
\text { from formal institutions } \\
\text { in last } 12 \text { months (\%) }\end{array}$ & $50.4 *$ & 4.7 & $66.8 *$ & 5.2 \\
\hline $\begin{array}{l}\text { Women have taken loan } \\
\text { from informal sources in } \\
\text { last } 12 \text { months }(\%)\end{array}$ & 33.0 & 37.2 & 26.3 & 22.3 \\
\hline $\begin{array}{l}\text { Women have taken loan } \\
\text { from SHG in last } 12 \\
\text { months (\%) }\end{array}$ & 45.7 & - & 60.9 & \\
\hline
\end{tabular}

Women have money that they can decide on their own on how to use (\%)

\section{$80.7 \quad 80.8 \quad 81.1^{*} \quad 71.2$}

ror

\begin{tabular}{|c|c|c|c|c|}
\hline \multicolumn{5}{|l|}{ Women solely own } \\
\hline Agricultural land (\%) & 10.4 & 11.8 & 12.8 & 9.3 \\
\hline Other land (\%) & 10.0 & 5.5 & 7.0 & 7.8 \\
\hline Large livestock (\%) & 20.3 & 15.5 & $22.4^{*}$ & 13.9 \\
\hline Small livestock (\%) & 52.0 & 53.1 & 59.6 & 58.3 \\
\hline Chickens, ducks,pigeons (\%) & 1.5 & 3.2 & $3.3 *$ & 12.4 \\
\hline $\begin{array}{l}\text { Farm equipment (non- } \\
\text { mechanized) (\%) }\end{array}$ & 6.4 & 8.0 & 8.3 & 4.3 \\
\hline $\begin{array}{l}\text { Farm equipment } \\
\text { (mechanized) (\%) }\end{array}$ & 0.0 & 0.0 & 4.2 & 2.3 \\
\hline $\begin{array}{l}\text { Non-farm business } \\
\text { equipment (\%) }\end{array}$ & 4.2 & 3.9 & 2.3 & 3.2 \\
\hline House or other structures (\%) & 32.5 & 32.2 & 32.5 & 39.2 \\
\hline Large consumer durables (\%) & 6.8 & 7.8 & 18.4 & 18.4 \\
\hline Small consumer durables (\%) & $27.3^{*}$ & 18.6 & 24.7 & 30.2 \\
\hline Cell phone (\%) & 49.5 & 43.0 & 53.2 & 51.5 \\
\hline Means of transportation (\%) & 29.7 & 28.1 & 27.6 & 34.6 \\
\hline
\end{tabular}

Women are an active member of

\begin{tabular}{lcccc}
\hline $\begin{array}{l}\text { Credit or microfinance } \\
\text { group (\%) }\end{array}$ & $40.1 *$ & 2.2 & $33.9 *$ & 0.8 \\
\hline A religious group (\%) & 4.0 & 2.8 & 7.1 & 3.0 \\
\hline & & & & \\
\hline
\end{tabular}




\section{Footnotes}

The Population Council confronts critical health and development issues - from stopping the spread of HIV to improving reproductive health and ensuring that young people lead full and productive lives. Through biomedical, social science, and public health research in 50 countries, we work with our partners to deliver solutions that lead to more effective policies, programs, and technologies that improve lives around the world. Established in 1952 and headquartered in New York, the Council is a nongovernmental, non-profit organization governed by an international board of trustees.

The Population Council conducts research and delivers solutions that improve lives around the world. Big ideas supported by evidence: It's our model for global change.

For additional copies, please contact:

\section{Population Council}

Zone 5A, Ground Floor

India Habitat Centre, Lodi Road

New Delhi, India 110003

Phone: 91 -11-24642901

Email: info.india@popcouncil.org

Website: www.popcouncil.org
1. All indicators are presented in percentages, unless and otherwise specified. Estimates for all the indicators, except the sociodemographic and household profile, are adjusted for women's education, religion, caste and wealth quintile, considering non- member as the reference category in the multivariate regression analysis run separately for the Mesha and non-Mesha areas.

2. Clean fuel for cooking includes electricity, LPG/ natural gas and biogas.

3. Flushed to pipe sewer system, flushed to septic tank, flushed to pit latrine, ventilated improved pit/ biogas pit latrine, latrine with slab, twin pit/composting toilet which are not shared with any other household.

4. Piped water into dwelling/yard/ plot, public tap/ standpipe, tube well or borehole, protected dug well, protected spring, rainwater, community RO plant.

5. Indicators are based on information from house-listing data.

6. Based on information from household schedule.

7. Village health, sanitation and nutrition day.

8. * refers to $p$-value $<0.05$ while comparing the proportions of SHG households with non-SHG households, for each indicator, within Mesha and non-Mesha areas separately.

The suggested citation is: Population Council. 2018. Baseline evaluation of Project Mesha in Bihar: Factsheet results 2017-2018. New Delhi: Population Council

Study supported by

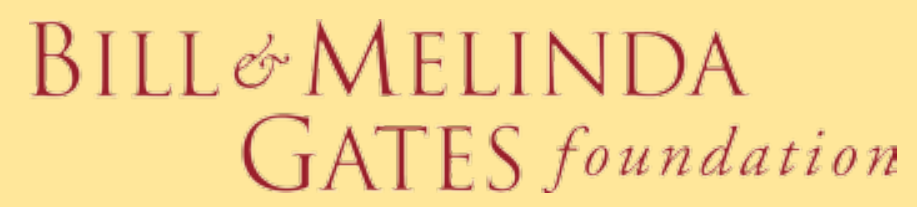

in collaboration with

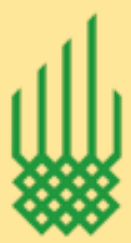

AGA KHAN FOUNDATION 